\title{
Does Corruption Increase the risk Premium on the West African Economic Monetary Union (WAEMU) Bond Market?
}

\author{
Mohamed Lamine MBENGUE \\ Gaston Berger University, Senegal \\ laminemb@gmail.com
}

\begin{abstract}
We study the relationship between corruption and risk premium in West African Economic Monetary Union (WAEMU) market bond. Our sample consists of bonds through a public offering and private placement. For this research data was collected from the stock exchange (Bourse Régionale des Valeurs Mobilières). Number of bonds, average corruption and average spread analysis was used to analyze the data. Most country in WAEMU states has a corruption index below 3.5. The results show that corruption score has negative effects on economic performance indicators and there was a predominance of private placement debt relative to debt through a public offering.
\end{abstract}

Keywords: Spread, corruption, WAEMU market bond,

\section{Introduction}

The West African Economic Monetary Union (WAEMU) market bond has been of a renewed interest in recent years. The development of market bond has had the effect of increasing the level of investors' management and the riskiness of their portfolios. Therefore, the various stakeholders in the market bond are increasingly attentive to the level of risk associated with issuing bonds and, thus, the concept of credit risk. The risk premium or credit spread represents the compensation required by investors to offset the overall risk by holding the security. In addition the credit spread characterizes the perception of credit risk by investors. Corruption has been shown to be associated with lower levels of investment and growth (Mauro, 1995); lower stock values (Lee \& Ng, 2002). This paper focuses on the role of corruption in determining the price in WAEMU bond market. The spread (or risk premium) reflects the higher default probability associated with WAMEU market debt. The paper focuses specifically on the role of corruption in determining the price in WAEMU market bond. Most studies have focused on which macroeconomic factors contribute to the likelihood of sovereign default (see, for example Edward, 1984; Eichengreen \& Mody, 1998).Who in a series of papers uses spread of emerging market. Our estimation includes macroeconomic variables by following Ciocchini, Durbin \& Ng (2003), Eichengreen and Mody (1998a) (1998b) (2001). But we include in our estimation other variables (dummy private placement, public offering and taxes revenues). Mobilizing tax revenue remains a preoccupation; the ratio is consistently 2.5 points below the average level of countries termed "fragile African states" and of West African Economic and Monetary Union states. Corruption plays an important role in determining the default risk, regardless of its impact on other types of economic performance. Therefore, studying the impact of corruption on the market is relevant for several reasons. First, the impact of corruption in determining the risk premium has never been studied in the WAEMU market bond. Second, based on ranking by Transparency International (2008), we notice that there is a region where corruption is widespread. The first country, Burkina Faso is ranked $80^{\text {th }}$ out of 181; followed by Senegal and Mali placed respectively, at the $85^{\text {th }}$ and $96^{\text {th }}$ places. The most corrupt countries in this area, as reported by Transparency International are Cote d'Ivoire $\left(151^{\text {st }}\right)$ and Guinea Bissau $\left(158^{\text {th }}\right)$. The remainders of the paper are sections that provide literature review, the methodology and empirical approach, the results and the conclusion. Last segment related to recommendations and conclusions of the study.

\section{Literature Review}

There are several studies that show how corruption in a country can affect asset prices in another country. David (2006) summarizes how corruption may affect stock and bond markets. Ciocchini, Durbin \& Ng (2003) examine the relationship between corruption and borrowing costs for governments and firms in emerging markets. They show using data from Transparency international as the most countries may pay a higher risk premium with issuing bonds. Ciocchini, Durbin, Ng David (2003) use bond spreads and are obtained by the difference between the initial yield of the bond and the risk free rate return of the 
same maturity. Their estimate includes macroeconomic variables such as GDP growth and external debt. Their empirical method is to estimate the impact of corruption on spreads, first by Ordinary Least Squares (OLS), and then through the heckman procedure. The vector of variables including to solvency includes the maturity of the bond, principal, dummies (the fixed rate bond, currency's issuer and private placement). In addition to the characteristics of the issuer (dummies: regions of issuers, corporate and governments bonds, classified by industry), they incorporate in their model the characteristics of the country (the ratio debt to GDP, dummy for the rescheduled debt, the real GDP growth, volatility of export growth, ratio reserves to bank debt, debt service to exports and the residue of sovereign rating). Understanding how corruption affects bond spreads is important for two reasons: First it helps know how to determine the probability of default in emerging markets. Most studies on this issue have focused on the macroeconomic factors that contribute to the probability of sovereign default (e.g. Edwards (1984), Boehmer and Megginson (1990) and Eichengreen and Mody (1998). Secondly, Ciocchini Durbin $\mathrm{Ng}$ (2003) observing how corruption affects economic growth, show that a higher corruption increase the borrowing cost on the international market, both for governments and firms in developing countries. For government debt, the impact of corruption is quite direct.

Corrupt officials can divert funds lent or other sources of revenue, limiting government's ability to meet its liabilities. Apart from the direct impact of corruption, several authors have shown that higher levels of corruption are associated with low tax revenues which in turn, will lower the government's capacity (Haque and Salay (1996), Tanzi and Tavoodi (1997), Johnson et al., (1999). Many studies have shown that corruption affects performance firms. The investigation into business environment (World Business Environment Surveys) conducted by the World Bank found that corruption is an obstacle to operations and business growth. For Butler, Fauver and Mortal (2009), a high level of corruption is associated with a higher credit risk and higher bonds yields. They also show that corruption has a negative relationship with bond ratings. Corruption can affect equity drivers like a firm's long term growth. Fisman (1991) examines the value of political connection in Indonesia by examining the stock prices of companies that have different degrees of political connections. He relates the news on the health of the former Indonesian President Suharto, to the stocks returns of these companies. Lee and Ng (2004) document the empirical relationship between the level of corruption within a country and the valuation of its corporations to shareholders. They find that firms from more corrupt countries trade at significantly lower market multiples, after controlling for other factors. They conclude that corruption has significant economic consequences on shareholder value. A sufficient reason to show that corruption can affect the market valuation is to associate with corporate governance. Ng and Qian (2004) study the impact of corruption on corporate governance. Their empirical analysis shows that corruption has a significant impact on governance and the value of the firm. Gelos and Wei (2006) show that a lower country transparency in a country is associated with a lower investment from international funds.

Measures of Corruption: Corruption is inherently subjective. Most studies use perception-based measures of corruption. The most popular surveys are: Economist Intelligence Unit, International Country Risk Guide, and Perception Index of Transparency International Corruption. Empirical studies (Asiedu and Freeman 2009) use measures of corruption that can be classified into three categories: internal, external, and hybrid. Internal measures are based on the experiences / perceptions of firms throughout the country. One of the advantages of internal measures is that they partly reflect business perceptions of investment risk. Firms operating in countries where corruption is widespread can become accustomed to forms of corruption and, thus, lower standards for judging corrupt practices (Cameron et al 2005). One limitation of internal measures is that the data are likely to be influenced by specific functions such as the firm size. Another drawback is related to the underestimation of corruption: respondents may be reluctant to provide answers related to corruption (Azfar and Murell, 2005). External measures are that assessments of analysts 'risk' (foreigners) are generally not based on personal experience, but on media reports. Consequently, the corruption scores reported by its "experts" do not give exactly the corruption score prevailing in the country, unlike the internal measures that are rated by the same entities and, therefore, the data are generally consistent and less prone to errors measurement. A number of studies have found that risk management by the rating agencies tend to be biased by poor countries and small countries (Ferri, 2004). The hybrid measures of corruption combines data from different sources of corruption as an index composite (internal and external measures). Hybrid measures, by their nature, reduce the problems associated with other measures of corruption. The composite index does not differentiate between various forms of corruption such as nepotism, embezzlement of public funds, or bribery. Asiedu and Freeman (2009) consider hybrid measures Corruption Perception Index of Transparency International and Corruption Index from Kaufman, Kraay and Mastruzzi (2005). 


\section{The Theoretical and Methodology Framework}

Corruption is a phenomenon observed in many countries. In Africa, it is devastating and can twin good economic policies into inefficient areas. The Corruption Perception index (CPI) refers to the level of corruption perception as seen by business people, country analysts, residents and non residents and rank from 10 to 1 . Chart 1 shows corruption is a reality in the West African region. Almost all member states of the Union have a corruption index below 3.5 the basis of the indices of 2008, Côte d'Ivoire and Guinea Bissau are the most corrupt countries in the zone.

Figure 1: Corruption Perception Index (Transparency International) WAEMU zone

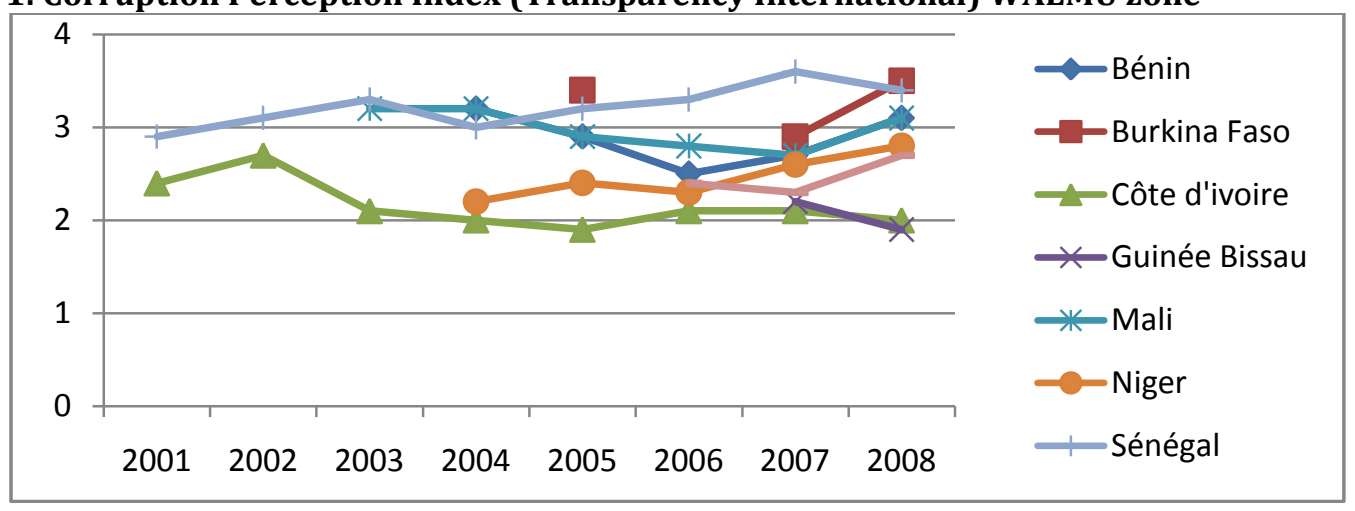

We rely on the following assumption: governments and firms that are in the most corrupt countries in the WAEMU zone have a high default risk and high spreads. The model is based on Ciocchini et al., (2003). S is the spread of the bond, $\mathrm{C}$ measures the level of corruption of the issuer in a country, $\mathrm{X}$ is a vector of macroeconomic variables contributing to the solvency. To test this hypothesis, we use bond spreads in WAEMU market bond from 1998 to 2010 with data from Transparency International in drawing on the work of Ciocchini et al., (2003), Eichengreen and Mody (1998) who use bond spreads in emerging spreads. The indices used by Transparency International represent subjective views and, inevitably, they are not accurate. Nevertheless they contain useful information about corruption.

Data and Variables: The data come from the Regional Stock Exchange (Bourse Régionale des Valeurs Mobilières BRVM) and the Conseil Régional de l'épargne publique et des Marchés Publiques (CREPMF). The sample consists of government and corporate bonds issued in WAEMU primary market. Macroeconomic variables come from the briefing notes and statistical database of the central bank.

Dependent variable: The dependent variable is ln (spread). The spread or premium risk is the difference between the return on risky bond and return on risk-free bond. We selected as benchmark the IFC (international Finance Corporation) and the Agence Française de Développement AFD. The two reference issuers have AAA rating. AFD wished to raise resources for two reasons: (i) corporate financing and WAEMU credit institutions; (ii) AFD proposes to create a new point on the yield curve to contribute to the establishment of a real curve. The IFC issue had a number of objectives: "(i) to support regional integration and promote development of capital market in West Africa; (ii) to introduce international best practices in bond documentation, syndication and selling techniques; (iii) reinforce credit differentiation and rationalize market regulations; and (iv), to provide investors with an alternative instrument in local currency of AAA quality".

Measure of corruption: In our model, we use the Corruption Perception Index of Transparency International and we retain the average over three years from the issuance date of the bond. For bonds, we also take the average of the corruption index of the issuing country. We use this index because it contains information from different sources and is used in other studies. 
Table 1: Number of bonds issues, the average corruption score and average spread a. Benchmark: International Finance Corporation (IFC)

\begin{tabular}{|c|c|c|c|c|c|c|c|}
\hline Country & $\begin{array}{l}\text { Number } \\
\text { of } \\
\text { Bonds }\end{array}$ & $\begin{array}{l}\text { Corporate } \\
\text { Bonds }\end{array}$ & $\begin{array}{l}\text { Government } \\
\text { Bonds }\end{array}$ & $\begin{array}{l}\text { Average } \\
\text { corruption } \\
\text { score }\end{array}$ & $\begin{array}{l}\text { Average } \\
\text { spread }\end{array}$ & $\begin{array}{l}\text { Average } \\
\text { government } \\
\text { spread }\end{array}$ & $\begin{array}{l}\text { Average } \\
\text { Corporate } \\
\text { spread }\end{array}$ \\
\hline Bénin & 12 & 8 & 4 & 2.88 & 195.83 & 162.5 & 212.5 \\
\hline Burkina & 13 & 11 & 2 & 2.67 & 189.62 & 112.5 & 196.82 \\
\hline Côte d'Ivoire & 43 & 35 & 8 & 2.16 & 245.7 & 200 & 260.625 \\
\hline Guinée Bis & - & - & - & 2 & & - & - \\
\hline Mali & 11 & 9 & 2 & 2.98 & 184.55 & 75 & 208.89 \\
\hline Niger & 1 & 1 & - & 2.46 & & & \\
\hline Senegal & 19 & 14 & 5 & 3.23 & 184.74 & 143.75 & 205 \\
\hline Togo & 15 & 13 & 2 & 2.46 & 240 & 150 & 253.84 \\
\hline BOAD & 8 & 8 & - & - & 62.5 & & 62.5 \\
\hline Shelter & 6 & 6 & & - & 158.33 & - & 158.33 \\
\hline
\end{tabular}

\section{b. Benchmark : Agence Française de Développement}

\begin{tabular}{|c|c|c|c|c|c|c|c|}
\hline Country & $\begin{array}{l}\text { Number } \\
\text { of } \\
\text { Bonds }\end{array}$ & $\begin{array}{c}\text { Corporate } \\
\text { Bonds }\end{array}$ & $\begin{array}{l}\text { Government } \\
\text { Bonds }\end{array}$ & $\begin{array}{l}\text { Average } \\
\text { corruption } \\
\text { score }\end{array}$ & $\begin{array}{l}\text { Average } \\
\text { spread }\end{array}$ & $\begin{array}{l}\quad \text { Average } \\
\text { government } \\
\text { spread }\end{array}$ & $\begin{array}{l}\text { Average } \\
\text { Corporate } \\
\text { spread }\end{array}$ \\
\hline Bénin & 12 & 8 & 4 & 2.88 & 145.83 & 112.5 & 162.5 \\
\hline Burkina & 13 & 11 & 2 & 2.67 & 139.62 & 87.5 & 146.82 \\
\hline Côte d'Ivoire & 43 & 35 & 8 & 2.16 & 195.7 & 150 & 210.62 \\
\hline Guinée Bis & - & - & - & 2 & & - & - \\
\hline Mali & 11 & 9 & 2 & 2.98 & 134.55 & 25 & 158.89 \\
\hline Niger & 1 & 1 & - & 2.46 & 125 & & 125 \\
\hline Senegal & 19 & 14 & 5 & 3.23 & 134.74 & 93.75 & 155 \\
\hline Togo & 15 & 13 & 2 & 2.46 & 190 & 100 & 203.85 \\
\hline BOAD & 8 & 8 & & - & 12.5 & & 12.5 \\
\hline Shelter & 6 & 6 & & - & 108.33 & - & 108.33 \\
\hline
\end{tabular}

Table1 (a) and (b) show the statistics of WAEMU market bond. We use two approaches. The first approach considers the IFC (spread1) as reference issuer; and the second uses as benchmark AFD (spread2). The first three columns include the number of bonds issued in each country, distinguishing between private and government issuers. There is a considerable variation in the number of bonds issuers in each country. Côte d'Ivoire and Senegal have more than $50 \%$ of the securities. In terms of issuance there is a predominance of private issuers (82\%) compared to government issuers (18\%). The fourth column of table1 shows the average level of corruption. Transparency International offers a scale of 0 to 10. ( 0 representing the most corrupt, and 10 the least corrupt). Our sample includes seven WAEMU countries; Guinea Bissau has not issued any bond. According to Transparency International Côte d'Ivoire, Niger, Togo, (among those issuing bonds) are the most corrupt; and Senegal, Benin, and Burkina Faso are considered the least corrupt of the WAEMU zone with notes of respectively 3.23, 2.88, and 2.67. The last three columns of table 1 classify spreads in each country in basis points. In general, the spreads are higher for the most corrupt such as Côte d'Ivoire (government securities) and corporate spreads are higher (with the level of corruption is greater). There is no clear relationship between the number of bonds issued and the classification level of corruption. 
Table 3: Univariate regression of log spreads on the corruption score

\begin{tabular}{|c|c|c|c|}
\hline & Echantillon total(a) & Gouvernement (b) & Entreprise (C) \\
\hline \multicolumn{4}{|l|}{$\log ($ spread1) } \\
\hline Corruption & $0.107(3.11)^{* *}$ & $0.17(1,70)$ & $0.083(3,008)^{* *}$ \\
\hline Constante & $2.590(27.62)^{* *}$ & $2.612(9,19)^{* *}$ & $2.566(34,15)^{* *}$ \\
\hline Observations & 115 & 22 & 93 \\
\hline $\mathrm{R}^{2}$ & 0.07 & 0.12 & 0.09 \\
\hline \multicolumn{4}{|l|}{$\log (\operatorname{spread} 2)$} \\
\hline Corruption & $0.163(3.56)^{* *}$ & $0.331(2,56)^{* *}$ & $0.11(2,90)^{* *}$ \\
\hline Constante & $2.608(20.88)^{* *}$ & $2.840(7,97)^{* *}$ & $2.51(24,30)^{* *}$ \\
\hline Observations & 115 & 22 & 93 \\
\hline $\mathrm{R}^{2}$ & & 0.24 & 0.08 \\
\hline
\end{tabular}

To look more explicitly at the correlation between corruption and spreads, we use the univariate regressions of log spreads on corruption score through two approaches. (IFC and AFD).The first column contains the total sample with government and corporate bonds. There's a high score corruption which's associated with higher spreads. The coefficients are statistically significant with a predominance of corporate bonds (60\% of bonds are securities Ivorian). Corruption is also correlated with several factors that affect spread (economic growth, debt, and political instability).

\section{Empirical approach}

We are specifically interest in how corruption affects spread for firms and government in WAEMU market bond. We use (almost) the same set of variable that Eichengreen et al (2001) and Ciocchini, Durbin \& Ng (2003) use. We add to the model the dummy variable (private placement and initial public offering) which is a specific character of the WAEMU zone. We use data on the spread (Benchmark IFC and AFD), maturity and amount of the bond. We use country characteristics (ratio of debt to GBP, ratio debt service to export, ratio reserves to GBP). Unlike Eichengreen (2001) and Ciocchini, Durbin \& Ng (2003) we include the dummy placement and taxes Revenues because in WAMU zone demand of corruption increase with the complexity of tax system, high tax rates may lead to more corruption by increasing the incentive for tax payers.

We use a least square regression (OLS) as:

$\mathrm{L}(\mathrm{S})=\mathrm{f}$ (credidom/GDP, Croist, corrupt, Debt/GDP, dummy placement, amount Reser/Import, Reserves/GDP, rectFisc, Serdett/exports). The variables are: amount, dummy placement (distinguishing private placement and initial public offering) and country characteristics (ratio debt to GDP, ratio reserves to imports, ratio debt service to exports, tax revenues, growth, domestic credit to GDP).

Table 4: Determinants of log spread

\begin{tabular}{lcc}
\multicolumn{2}{l}{ Table 4: Determinants of log spread } \\
\hline Domestic Credit/GDP & Logspread1 & logspread2 \\
GDP Growth & $0,001(0.33)$ & $0.003(0.79)$ \\
Corruption & & $0.0004(0.03)$ \\
Debt/GDP & $-0,067(-2.14)^{*}$ & $-0.09(2.01)^{*}$ \\
Public Offering & & $0.004(4.41)^{* *}$ \\
Private Placement & $0.212(3.85)^{* *}$ & $0.211(2.90)^{* *}$ \\
Amount & $0,254(4.25)^{* *}$ & $0.305(3.94)^{* *}$ \\
Reserves/ imports & $-2.66^{\mathrm{E}}-12(-3.33)^{* *}$ & $-3.27 \mathrm{E}-12(-3.26)^{* *}$ \\
Réserves/GDP & $-0.003(-0.31)$ & $0.039(2.87)^{* *}$ \\
Taxe Revenues & $-0.013(-0.51)$ & $-0,073(-2,26)^{*}$ \\
Debt service/ exports & & $1.55 \mathrm{E}-05(0.61)$ \\
Constant & $0.003(2.34)^{*}$ & $0.004(2.59)^{* * a}$ \\
Observations & $2.31(19.68)^{* *}$ & $1.77(8.87)^{* *}$ \\
$\quad \mathrm{R}^{2}$ & 115 & 115 \\
F-stat & 0.48 & 0.59 \\
P>F & 12.54 & 3.55 \\
\hline
\end{tabular}

T statistics in parentheses: dummies public offering and private placement $\left({ }^{*}\right)$ significant at $5 \%\left({ }^{* *}\right)$ significant at $1 \%$ 
Discussion: In theory, corruption should affect the default risk of governments and firms in different ways and there good reasons to think that other determinants of default risk are different as well. When we use the first approach (IFC) private offering and private placement are more significant than the second approach (AFD). We note that the IFC issue in WAEMU had a number of developmental objectives. Table 4 presents the results for the spread equation obtained by OLS. The two columns (a) and (b) presents the results for the spreads (total sample), the coefficient of corruption score is negative and significant confirming that the issuers in the most corrupt countries in WAEMU zone pay a risk premium. The first column of table 4 shows the results as IFC benchmark. The first approach, all variables are significant with the exception of domestic credit/GDP and growth rate. The second column shows the results of the determinants of logspreads (benchmark AFD). The following macroeconomic factors affect the countries and firms; the corruption score has negative effects on economic performance indicators. Table3 shows, , that all the coefficients of corruption score are significant at $1 \%$ ( except for government securities logspread1). There was a predominance of private placement debt relative to debt through a public offering. The lack of significance for government securities is explained by the sample size (22 securities) against (93 securities) for corporate bonds but also the level of premium risk. It is found that the spreads on the market bond are abnormally low to benchmark issuers IFC and AFD. Minor discrepancies can be explained by the lack of informational efficiency and excess liquidity in the market that allows issuers to apply for low risk premium.

\section{Conclusion and Recommendations}

We have shown how corruption affects the probability of default on WAEMU market bond. Our results show that the perception of corruption has an impact on the securities through a public offering and private placement and that this impact has the same degree. Empirical tests also show that corruption is a sign of poor macroeconomic management. Risks associates with the development of government securities in the WAEMU zone are real and are largely due to the recurrence of a number of bad management of public debt. It's necessary to develop coherent policies that are sustainable and the best way to strengthen capital markets and reduce risk premiums. Some recommendations should be made:

- It is important to improve the ranking of the WAEMU countries on the Corruption Perception index

- Enhancing transparency in the management of public finances by the widespread use of agencies rating in all WAEMU countries.

Limitation and Scope of further Research: A central question that we not addressed in the study is how exactly corruption affect sovereign and private spreads.

- We can also associate the indices of Transparency International and Kaufmann, Kraay, Mastruzzi (2005) and another determinant the solidity of the institutions with CPIA (Country Policy and Institutional Assessment) index.

- Then integrate the convergence criterion on the debt ratio supplemented by two criteria of liquidity, i.e. the ratio of public debt service / budget revenue and domestic debt service / budget revenue to strengthen the preventive management of public debt in this area.

- Sample of 115 bonds was focused in the study. Future research requires a larger

- sample for more accurate results (include for example bonds issued by the central bank "Banque Centrale des Etats de l'Afrique de l'Ouest (BCEAO)

\section{References}

Asiedu, E. \& Freeman, J. (2009). The Effect of Corruption on Investment Growth: Evidence from Firms in Latin America, Sub-Saharan Africa and Transition Countries. Review of Development Economics, 13(2), 200- 214.

Azfar, O. \& Murrell, P. (2005). Identifying Reticent Respondents: Assessing the quality of Survey Data on Corruption and Values. Economic development and cultural change EDCC

Boehmer, E. \& Megginson, W. L. (1990). Determinants of Secondary Market Prices for Developing Country Syndicated Loans. Journal of Finance, 45(5), 1517- 40.

Butler, W. A., Fauver, L. \& Sandra, M. (2009). Corruption, Political Connections, and Municipal Finance. The review of financial studies, 3, 22-47.

Cameron, L., Chaudhuri, A., Erkal, N. \& Gangadharan, L. (2005). Do Attitudes Towards Corruption Differ Across Cultures? Experimental Evidence from Australia, India, Indonesia and Singapore? Working Paper No. 943. University of Melbourne 
Ciocchini, F., Durbin, E. \& Ng, D. (2003). Does corruption Increase Emerging Market Bond Spread. Journal of Economics \& Business, 1(2).

David, N. (2006). The impact of corruption on financial markets. Managerial Finance, 32(10).

Edwards, S. (1984). LDC foreign borrowing and default risk: An empirical investigation, 1976-80. American Economic Review, 74(4), 726-734.

Eichengreen, B. \& Mody, A. (1998a). Interest rates in the north and capital flows to the south: Is there a missing link? International Finance, 1(1), 35-57.

Eichengreen, B. \& Mody, A. (1998b). What explains changing spreads on emerging-market debt: Fundamentals or market sentiment? NBER Working Paper, 6408

Eichengreen, B. \& Mody, A. (2001). Flight to quality: Investor risk tolerance and the spread of emerging markets crises. In S. Claessens \& K. Forbes (Eds.). International financial contagion (pp. 129-156). Kluwer Academic Publishers.

Ferri, G. (2004). More Analysis, Better Ratings: Do Rating Agencies Invest Enough in Less Developed Countries. Journal of Applied Economics, 7(1), 77-98.

Fisman, R. (1991). Estimating the value of political connections. American Economic Review, 94(4), 1095102.

Gelos, R. G. \& Wei, S. J. (2006). Transparency and international investor Behaviour. IMF Working Paper $02 / 174$.

Haque, N. \& Sahay, R. (1996). Do Government Wage Cuts Close Budget Deficits? Costs of Corruption. International Monetary Fund Staff Papers, 43(4), 754-78.

Johnson, S., Kaufmann, D. \& Zoido-Lobaton, P. (1999). Corruption, Public Finances, and the Unofficial Economy, World Bank Policy Research Paper, 2169.

Kaufman, D., Kraay, A. \& Mastruzzi, M. (2005). Measuring Governance Using Cross- Country Perceptions Data. World Bank Working Paper. Washington, DC: World Bank.

Lee, C. \& Ng, D. (2002). Corruption and International Valuation: Does Virtue Pay, Mimeo, Cornell University.

Mauro, P. (1995). Corruption and Growth. Quarterly Journal of Economics, 110, 681-712.

Ng, D. \& Qian, L. (2004) Corruption and corporate governance, mimeo, Cornell University, Ithaca, NY.Tanzi, V., Tanzi, V. \& Davoodi, H. (1997). Corruption, public investment and growth. IMF Working Paper, WP/137/39. 